\title{
INFLUENCE OF COCONUT SHELL ADDITION ON PHYSICO-MECHANICAL PROPERTIES OF WOOD PLASTIC COMPOSITES ${ }^{1}$
}

\author{
Éverton Hillig ${ }^{2 *}$, Ignacio Bobadilla ${ }^{3}$, Ademir José Zattera ${ }^{4}$, Érick Agonso Agnes de Lima ${ }^{5}$ and Raquel \\ Marchesan ${ }^{6}$
}

\footnotetext{
${ }^{1}$ Received on 09.08.2016 accepted for publication on 24.08.2017.

${ }^{2}$ Universidade Estadual do Centro-Oeste, Departamento de Engenharia Florestal, Irati, Paraná - Brasil. E-mail: <hillig@hotmail.com>.

${ }^{3}$ Universidad Politécnica de Madrid, Departamento de Ingeniería y Gestión Forestal y Ambiental. E-mail: <i.bobadilla@upm.es>.

${ }^{4}$ Universidade de Caxias do Sul, Centro de Ciências Exatas e Tecnologia, Caxias do Sul, Rio Grande do Sul - Brasil. E-mail: <ajzattera@terra.com.br>.

${ }^{5}$ Universidade Estadual do Centro- Oeste, Programa de Pós-Graduação em Ciências Florestais, Irati, Paraná, Brasil. E-mail: <erick_agnes@hotmail.com>.

${ }^{6}$ Universidade Federal do Tocantins, Professora do curso de Engenharia Florestal, Gurupi, Tocantins, Brasil. E-mail: $<$ raquelmarchesan@yahoo.com.br>.

*Corresponding author.
}

ABSTRACT - In this study, composites with three types of thermoplastic matrix and cellulosic material in
a proportion of $40 \%$ were produced. The three thermoplastic matrices were high density polyethylene (HDPE),
polypropylene (PP) and low density polyethylene (LDPE), and the cellulosic materials were pure wood flour
(Pinus taeda L) or a mixture of wood flour and coconut shell flour (Cocus nucifera L) in equal ratios. The
objective was to evaluate the influence of addition of coconut shell on the physico-mechanical properties
(density, strength and rigidity) and the distribution of the cellulosic material in the thermoplastic matrix
of the manufactured composites. It was found that the composites had a satisfactory distribution of wood
flour in thermoplastic matrices, but the addition of coconut shell promoted bubble formation in the resulting
pieces and, thus, interfered with the material properties. The use of a coupling agent promoted interfacial
adhesion (cellulose - thermoplastic matrix), which was better in high density polyethylene composites, followed
by polypropylene and low density polyethylene. In general, the coconut shell addition caused a decrease of
all properties compared to composites made with Loblolly Pine. In addition, the interactions between thermoplastic
type and cellulosic matrix type have been statistically confirmed, which caused variations in the studied properties

Keywords: Polyolefins; Pinus taeda; Cocus nucifera.

\section{INFLUÊNCIA DA ADIÇÃO DE CASCA DE COCO NAS PROPRIEDADES FÍSICO-MECÂNICAS DE COMPÓSITOS POLÍMERO/MADEIRA}

\begin{abstract}
RESUMO - Neste estudo, foram produzidos compósitos com três tipos de matriz termoplástica e material celulósico em uma proporção de 40\%. As três matrizes termoplásticas foram polietileno de alta densidade (HDPE), polipropileno (PP) e polietileno de baixa densidade (LDPE), e os materiais celulósicos foram farinha de madeira pura (Pinus taeda $L$ ) ou uma mistura de farinha de madeira e farinha de casca coco (Cocus nucifera $L$ ) em proporções iguais. O objetivo foi avaliar a influência da adição de casca de coco nas propriedades fisico-mecânicas (densidade, resistência e rigidez) e a distribuição do material celulósico na matriz termoplástica dos compósitos. Verificou-se que os compósitos apresentaram uma distribuição satisfatória da farinha de madeira nas matrizes termoplásticas, mas a adição de casca de coco promoveu a formação de bolhas nas peças e, assim, interferiram com as propriedades do material. O uso de um agente de acoplamento promoveu melhor adesão interfacial (celulose - matriz termoplástica) nos compósitos com polietileno de alta densidade, seguidos do polipropileno e do polietileno de baixa densidade. Em geral, a adição de casca de coco causou uma diminuição de todas as propriedades em comparação com os compósitos produzidos com pinus. Além disso, as interações entre o tipo de termoplástico e o tipo de matriz celulósica foram confirmadas estatisticamente, e causaram variações nas propriedades estudadas.
\end{abstract}

Palavras-Chave: poliolefinas; Pinus taeda; Cocus nucifera. 


\section{INTRODUCTION}

In accordance with SIMPLÁS (2008), wood plastic composites (WPCs) are combinations of plastics and natural fibers manufactured by thermoplastic processing technology. This technology, which results in a new product with new properties, remains one of the fastest growing segments within the plastics industry. Besides, this technological innovation achieved by extrusion industries, gives opportunity for the timber industry to enter the petrochemical segment. The resulting products are used in construction, automotive, carpentry and furniture industry and other outdoor applications, generally decorative.

The polymers commonly used for the composites production are high density polyethylene (HDPE), low density polyethylene (LDPE), polypropylene (PP), and polyvinyl chloride (PVC), which can be used virgins, recycled or in mixtures (El-Haggar and Kamel, 2011). Additives, such as lubricants, pigments, stabilizers, coupling agents and biocides, as well as inorganic fillers, are added to the polymer and fibers.

In Optimat Ltda and Merl Ltda (2003), it was verified that polyethylene (HDPE and LDPE) was used in 70\% of the WPC products produced, and that only Trex. Inc., in the United States of America, used between 20 and 30 thousand tons per year of recycled LDPE films for the WPC decking production.

Lee et al. (2010) evaluated the physico-mechanical properties and the wood flour dispersion of Trema orientalis (L.) Blume in composites produced with five types of thermoplastic polymers (HDPE, LDPE, PP, Polystyrene-PS and recycled HDPE).The authors found lower mechanical properties (MOR, MOE and internal bonding) values for the LDPE composites than the others, however, a more homogeneous wood flour dispersion in this polymer type was observed.

Regardless of the polymer type, several other factors may interfere with the final product quality, and two of them may be highlighted: the use of coupling agents to improve the compatibility between polymer (apolar) and the fiber (polar), and the wood flour type used.

With respect to the coupling agents, Tobón et al. (2014) incorporated Teline monspessulana (L.) O. Bolós and Vigo fibers in the mixture of LDPE and high impact polystyrene (HIPS), in order to evaluate the efficiency of the coupling agent dicumyl peroxide (DCP) in this composite type. It was verified that the mixture of LDPE and HIPS had a negative effect on the composites mechanical properties due to the lack of crosslinks. The DCP use, however, had a positive effect, improving adhesion and mechanical properties when the fiber proportions were up to $50 \%$.

Gubbström et al. (2010) studied the silane use asa cross-linking promoter in LDPE composites and "lignosil BK 40/90" wood flour. The addition of silane increased the crosslinking degree with consequent increase in strength, stiffness and creep of the composites, whenit was compared to those without crosslinking promoter. Oliveira et al. (2010) evaluated the effect of (PE)/maleic anhydride grafted in the compatibilization of composites produced with LDPE and green coconut fiber in the $5 \%$ ratio, verifying that compatibilized composites presented higher tensile strength and stiffness than non-compatibilized composites.

Regarding the wood flour type used, the effects are related to the plant species from which it is obtained, and also to the treatment given to the fibers in order to obtain the flour. Hillig et al. (2008) verified that the sawdust type influenced on the HDPE matrix composites properties. The authors concluded that these differences were caused in part by the granulometry of each sawdust used, but also by other characteristics inherent to each wood species.

Various types of lignocellulosic fibers are available in many countries in the form of agroindustrial residues (Silva et al., 2009). According to the authors, the production of coconut in 2007 was 2,017 million fruits. Coconut shell fiber is commercially available for sale in some companies in Brazil, and among its applications, its use stands out in the timber sector in mixture with wheat flour, as extender in the bonding of plywood panels, and its use as reinforcement or filler in thermoplastics and thermosets.

In other applications and in some experimental studies, such as in the production of particleboards, the use of coconut fibers in a proportion of up to $30 \%$ has increased static bending strength, stiffness and also hardness. However, there was a decrease in perpendicular tensile strength indicating that the material affected the bonding properties (Colli et al., 2010).

This study aimed to evaluate the effect of polymer type and the lignocellulosic material, especially the coconut shell, in the physico-mechanical properties

Revista Árvore. 2017;41(4):e410412 
of composites with different plastic matrix (HDPE, LDPE, PP), and the effect of using HDPE graphitized with maleic anhydride as an coupling agent.

\section{MATERIALAND METHODS}

\subsection{Raw material}

For the production of the analyzed composites, coconut shell flour (Cocus nucifera L.) and Loblolly Pine wood flour (Pinus taeda L.) were used, both being of fine grain type, and they were provided by a company that produces these materials.

As thermoplastic matrix of composite, three polymers were used: a) virgin low density polyethylene (LDPE) and recycled in a 50\% blend, being the virgin LDPE grade BC818-Braskem with density of $0.918 \mathrm{~g} . \mathrm{cm}^{-3}$ and melt flow index of 8.3 g. $\mathrm{min}^{-1}\left(190^{\circ} \mathrm{C} / 2.16 \mathrm{~kg}\right)$; b) high density polyethylene (HDPE) grade ES 6004 Braskem with density of $0.960 \mathrm{~g} . \mathrm{cm}^{-3}$ and melt flow index of 0.35 g. $\mathrm{min}^{-1}\left(190^{\circ} \mathrm{C} / 2.16 \mathrm{~kg}\right)$; and c) polypropylene (PP) grade $\mathrm{H} 503$ Braskem with density of 0.905 g.cm ${ }^{-3}$ and melt flow index of $3.50 \mathrm{~g} \cdot \mathrm{min}^{-1}\left(190^{\circ} \mathrm{C} / 2.16 \mathrm{~kg}\right)$ (BRASKEM, 2015).

The polybond 3029 coupling agent was used in a $5 \%$ ratio of polymer by weight. According to the manufacturer, the additive is HDPE maleic anhydride grafted (MA) and is specially designed for use in polyethylene composite materials filled with natural fibers. Their properties are $\mathrm{Tm}=130{ }^{\circ} \mathrm{C}$, density $=0.95$ g. $\mathrm{cm}^{-3}$ and MA content $=1.5-1.7 \%\left(\right.$ ADDIVANT $\left.{ }^{\mathrm{TM}}, 2013\right)$.

\subsection{Granulometry of the flour types used}

The granulometry determination of the two types of flour was carried out using five Tyler sieves with numbers 16, 28, 42, 65 and 270 mesh. The test was performed with a mechanical stirrer over a period of 10 minutes at maximum intensity. The granulometric profile was obtained by the mass fraction retained in each sieve in a sample of $200 \mathrm{~g}$ of each flour types.

The particle diameter $(\mathrm{dp})$, whose volume is equal to the mean volume of all particles, was calculated by equation 1 .

$$
d_{p}^{3}=\frac{1}{\sum\left(\frac{x_{i}}{d_{i}^{3}}\right)}
$$

Where: $x_{i}=$ mass fraction retained between two sieves; $d_{i}=$ mean of the mesh openings of the two sieves.

\subsection{Experimental design}

To reach the objectives of the study, the test specimens were produced by varying the polymer type and the flour type, thus establishing a factorial design with two factors, which were polymer and flour, and three levels in each factor, three polymer types and two flour compositions plus the pure matrix. The experimental model is summarized in Table 1.

\subsection{Composites production and molding}

The composites were produced using a co-rotating twin screw extruder MH-COR-20-32 with $20 \mathrm{~mm}$ thread diameter, diameter length ratio L/ D 32 and with degasing zone. The extrusion was carried out with temperatures in the different heating zones varying according to the following profile: $160,160,180,180,185,185^{\circ} \mathrm{C}$; in the degasing zone: $185,190,190^{\circ} \mathrm{C}$ and with melt temperature equal to $220^{\circ} \mathrm{C}$. The rotation was set at 220 RPM.

The twin-screw extrudate was machine granulated and then oven dried at $100^{\circ} \mathrm{C}$ for 24 hours. Then, it was packed in plastic bags for further processing injection of the specimens.

The injection molding was performed in the Himaco LH 150-80 injector, with temperatures varying between 185 and $200^{\circ} \mathrm{C}$, depending on the injected mixture.

\subsection{Scanning electron microscopy}

For the flour dispersion analysis in the polymeric matrix, scanning electron microscopy (SEM) was carried out in a Tescan electronic microscope, model VEGA3, with magnifications varying between 500 and 3,000 times and

Table 1 - Experimental design.

Tabela 1-Modelo Experimental.

\begin{tabular}{|c|c|c|}
\hline Treat. & $\begin{array}{l}\text { Polymer } \\
\text { matrix }\end{array}$ & Flour type $(40 \%)^{2}$ \\
\hline Т 1 & HDPE & {[} \\
\hline T2 & HDPE & Pinus taeda \\
\hline T3 & HDPE & $\left(\right.$ Pinus taeda + Cocus nucifera shell) ${ }^{3}$ \\
\hline T 4 & PP & - \\
\hline T 5 & $\mathrm{PP}$ & Pinus taeda \\
\hline T 6 & PP & $(\text { Pinus taeda }+ \text { Cocus nucifera } \text { shell })^{3}$ \\
\hline T7 & $\mathrm{LDPE}^{1}$ & - \\
\hline T 8 & LDPE $^{1}$ & Pinus taeda \\
\hline T9 & $\mathrm{LDPE}^{1}$ & (Pinus taeda + Cocus nucifera shell) ${ }^{3}$ \\
\hline
\end{tabular}


$10 \mathrm{KV}$ of incident beam energy. The specimens were fractured by flexure to observe the internal composition of the composite and, for this purpose, the fractured surface was covered with a gold conducting layer of approximately $10 \mathrm{~nm}$. To obtain the microphotographs, the samples were placed on individual $1 \mathrm{~cm}$ diameter circular aluminum supports.

\subsection{Physico-mechanical tests and statistical analysis}

The specimens were submitted to static bending and tensile tests, performed according to ISO-178/10 and ISO527 (1-2)/ 12 standards, respectively. The density of the specimens was also determined by the hydrostatic balance method, according to the NBR 11941 (ABNT, 2003) standard.

Before being tested, the specimens underwent a stabilization period of 72 hours and were conditioned in a climatic chamber at $23^{\circ} \mathrm{C}$ and $50 \%$ relative humidity.

The properties results were submitted to analysis of variance (ANOVA) between treatments and between factors (Table 1). The analysis between factors was complemented by the Duncan test and allowed to evaluate the main effects. The ANOVA between treatments was also complemented by the Duncan test, which allowed to compare the results with references, as well as to evaluate the interaction between the factors studied. The statistical analysis was performed at a $5 \%$ error probability.

\section{RESULTS}

\subsection{Flour sieve analysis}

Figure 1 shows the frequencies of each particle size for each type of flour used.

Approximately $92 \%$ of the fine Loblolly Pine flour particles have a particle size between 0.054 and 0.354 $\mathrm{mm}$. The coconut shell flour showed to be even thinner, but with distribution in more size classes than the Loblolly Pine flour.

The particle diameter, whose volume is equal to the mean volume of all particles, was 0.0143 and 0.0196 $\mathrm{mm}$ for coconut shell and fine Loblolly Pine, respectively.

\subsection{Scanning electron microscopy}

In Figure 2, scanning electron microscope photographs of the fracture surface taken from the tensile and the static bending test specimens can be observed.

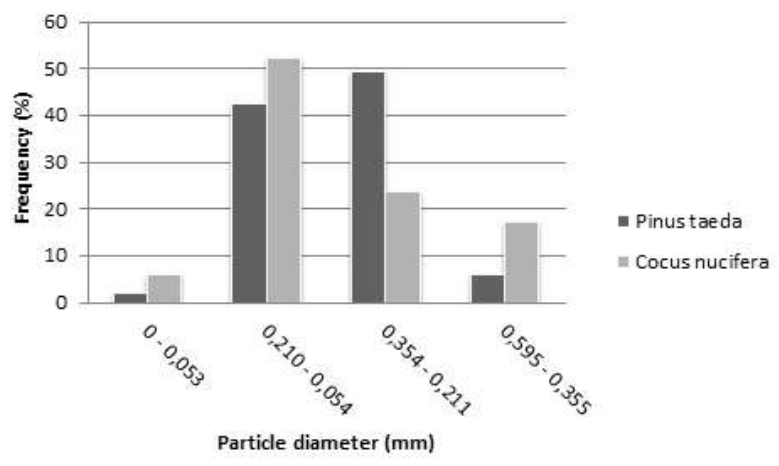

Figure 1 - Particles frequency per diameter class. Figura 1 - Freqüencia das partículas por classe de diâmetro.

\subsection{Physico-mechanical properties of composites}

Table 2 presents the mean values of the physicomechanical properties of the evaluated composites.

Table 3 presents the mean values of the composite properties separated by factor, e.g., matrix type and flour type, as well as the statistical analysis for the main factors and the interaction between them.

The polymer matrix type factors and the flour type demonstraded influence on all evaluated properties, presenting, in addition, a statistically significant interaction for all the properties. Therefore, the discussion of the main effects influence was made from Table 3, while the discussion of interaction between the factors is based on Table 2 .

\section{DISCUSSION}

\subsection{Dispersion of the flour in the polymer matrix}

In the Figure 1, the photos of the composites specimens 3 and 6 (T3 and T6) show that the flour dispersion was not homogeneous and that there were voids in the mixtures. Composites 2 and 4 (T2 and T4) have a more homogeneous structure and no voids were found in their structure.

The presence of large voids in the composite sample image prepared with HDPE and wood flour mixed with coconut shell (T3) can be clearly observed, which also altered the density of these specimens (see Table 2).

Composites 8 and 9, produced with LDPE matrix, show a more fibrous structure than composites produced with HDPE and PP. The composite 9 also has voids, though to a lesser degree.

Revista Árvore. 2017;41(4):e410412 


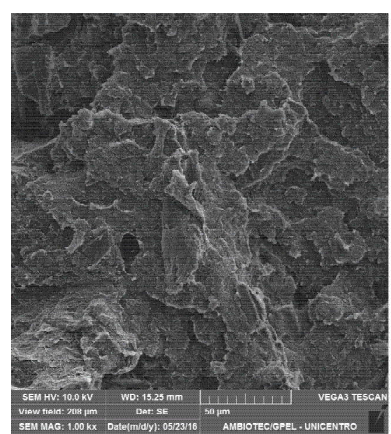

$121000 \times$ tensile

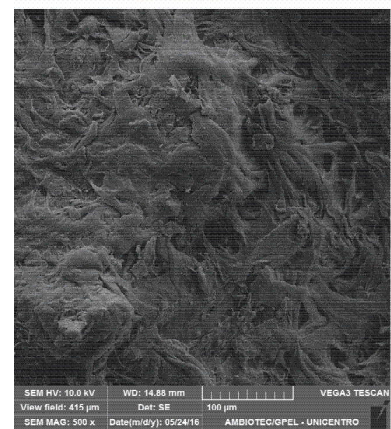

T3 $500 \mathrm{x}$ tensile

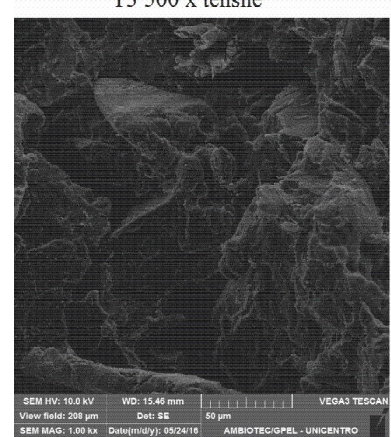

T5 $1000 \times$ tensile

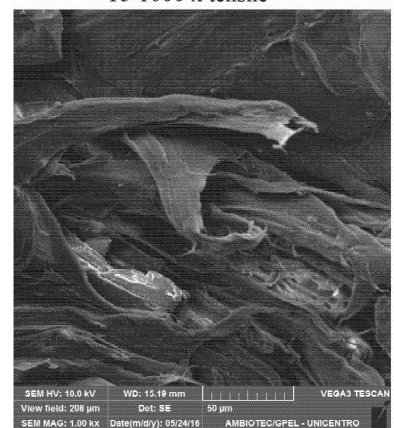

T8 $1000 \times$ tensile

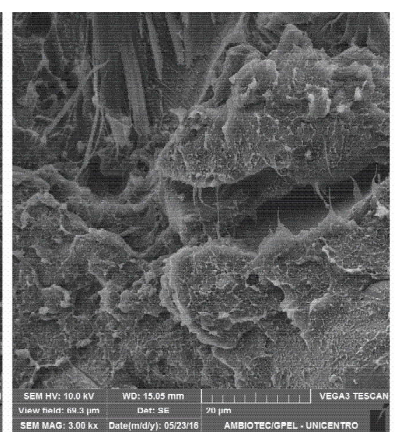

$123000 \times$ tensile

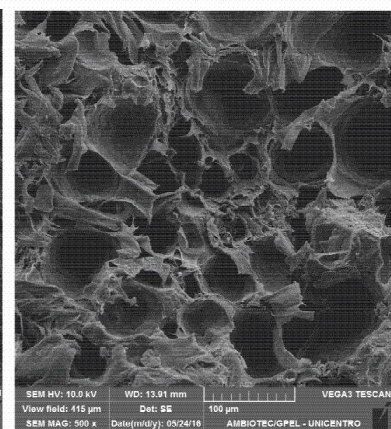

T3 $500 \mathrm{x}$ bending

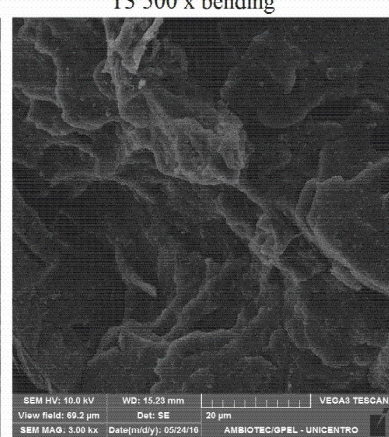

T5 $3000 \times$ tensile

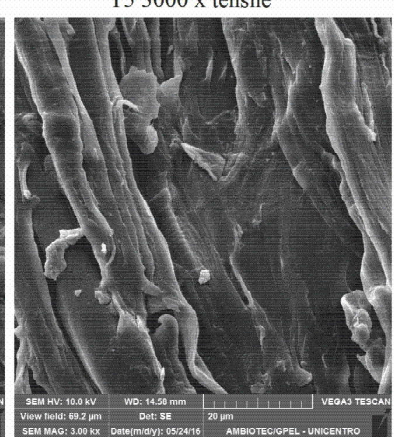

T8 $3000 \times$ tensile

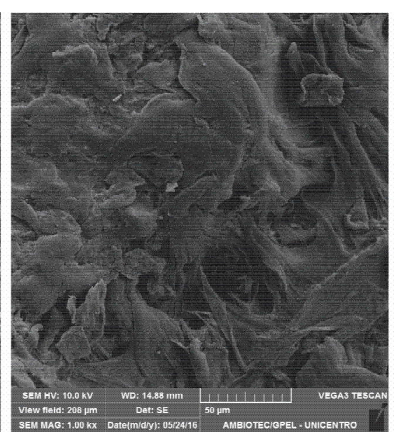

T3 $1000 \mathrm{x}$ tensile

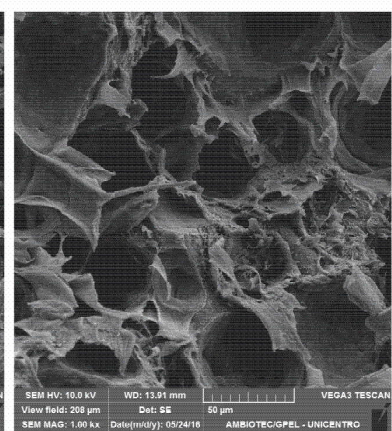

T3 $1000 \mathrm{x}$ bending

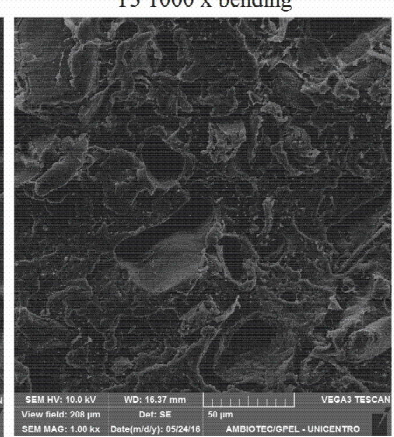

T6 $1000 \times$ tensile

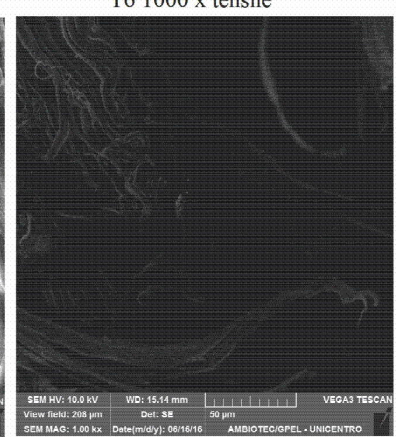

T9 $1000 \mathrm{x}$ bending

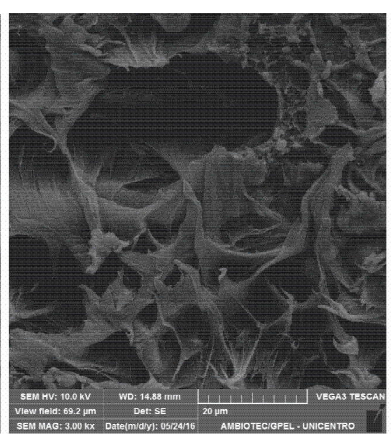

T3 $3000 \times$ tensile

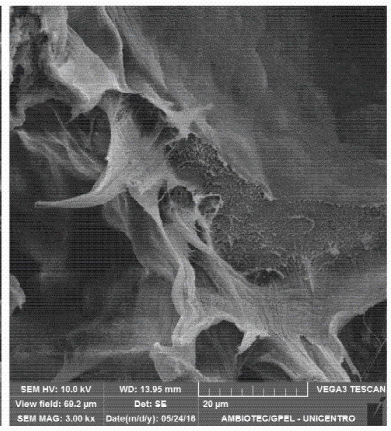

T3 $3000 \mathrm{x}$ bending

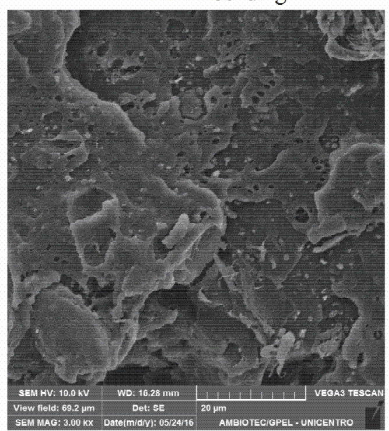

T6 $3000 \times$ tensile

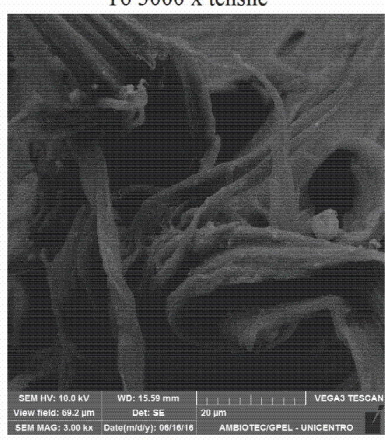

T9 $3000 \mathrm{x}$ bending

Figure 2 - Fracture surface micrographs of tensile and static bending test specimens obtained by scanning electron microscopy (SEM).

Figura 2 - Micrografias da superficie de fratura dos corpos de prova de tração e de flexão obtidas por microscopia eletrônica de varredura (SEM). 
Table 2 - Physico-mechanical properties of specimens produced with different composites mixtures.

Tabela 2 - Propriedades físico-mecânicas dos corpos de prova produzidos com as diferentes misturas de compósitos.

\begin{tabular}{|c|c|c|c|c|c|c|c|c|}
\hline Treat. & Polymer & Flour $(40 \%)^{2}$ & $\operatorname{Dt}\left(\mathrm{g} / \mathrm{cm}^{3}\right)$ & $\mathrm{St}(\mathrm{MPa})$ & Et(MPa) & $\operatorname{Dsb}\left(\mathrm{g} / \mathrm{cm}^{3}\right)$ & MOR(MPa) & $\mathrm{MOE}(\mathrm{MPa})$ \\
\hline $\mathrm{T} 1$ & HDPE & $\longrightarrow$ & $0,95 \mathrm{c}$ & $17,1 \mathrm{c}$ & $891 \mathrm{c}$ & $0,95 \mathrm{~d}$ & $26,0 \mathrm{~d}$ & $1100 \mathrm{c}$ \\
\hline $\mathrm{T} 2$ & HDPE & $P t$ & $1,05 \mathrm{~g}$ & $25,4 \mathrm{de}$ & $1583 \mathrm{e}$ & $1,04 \mathrm{~g}$ & $49,9 f$ & $1889 d$ \\
\hline T 3 & HDPE & $\mathrm{PtC}^{3}$ & $1,05 \mathrm{~g}$ & $17,4 \mathrm{c}$ & $1613 \mathrm{e}$ & $0,85 \mathrm{a}$ & $32,2 \mathrm{e}$ & $1053 \mathrm{c}$ \\
\hline $\mathrm{T} 4$ & P P & - & $0,91 \mathrm{a}$ & $28,3 \mathrm{f}$ & $1179 d$ & $0,91 b$ & $50,0 \mathrm{f}$ & $1135 \mathrm{c}$ \\
\hline T 5 & P P & $P t$ & $1,01 \mathrm{f}$ & $26,5 \mathrm{ef}$ & $2178 \mathrm{~g}$ & $0,98 \mathrm{e}$ & $54,9 \mathrm{~g}$ & $2195 \mathrm{e}$ \\
\hline Т 6 & P P & $P t C^{3}$ & $1,02 f$ & $23,6 \mathrm{~d}$ & $1942 f$ & $0,99 \mathrm{e}$ & $49,9 f$ & $1774 d$ \\
\hline T 7 & $\mathrm{LDPE}^{1}$ & - & $0,93 b$ & $12,0 b$ & $232 a$ & $0,93 \mathrm{c}$ & $10,0 \mathrm{a}$ & $206 a$ \\
\hline T 8 & $\mathrm{LDPE}^{1}$ & $P t$ & $0,98 d$ & $9,2 \mathrm{a}$ & $538 b$ & $1,02 \mathrm{f}$ & $20,3 \mathrm{c}$ & $542 b$ \\
\hline T 9 & $\mathrm{LDPE}^{1}$ & $P_{t} C^{3}$ & $0,99 \mathrm{e}$ & $7,9 \mathrm{a}$ & $432 b$ & $0,99 \mathrm{e}$ & $17,4 \mathrm{~b}$ & $473 b$ \\
\hline
\end{tabular}

Treat. $=$ treatment; ${ }^{1} 50 \%$ virgin high density polyethylene $+50 \%$ recycled high density polyethylene. ${ }^{2}$ dry weight basis ratio. ${ }^{3} 20 \%$ Pinus taeda flour and $20 \%$ Cocus nucifera shell flour. Pt $=$ Pinus taeda. PtC $=$ Pinus taeda + Cocus nucifera. Dt $=$ density of tensile specimens; $\mathrm{St}=$ tensile strength; $\mathrm{Et}=$ tensile modulus; $\mathrm{Dsb}=$ density of static bending specimens; $\mathrm{MOR}=$ static bending strength; $\mathrm{MOE}=$ static bending modulus; Means followed by the same letters do not differ statistically by Duncan test at $5 \%$ error probability.

Table 3 -Mean values of the pieces properties produced by injection presented by factor studied.

Tabela 3 - Valores médios das propriedades das peças produzidas por injeção apresentadas por fator estudado.

\begin{tabular}{lccccccc}
\hline Factor & Type & $\mathrm{Dt}\left(\mathrm{g} / \mathrm{cm}^{3}\right)$ & $\mathrm{St}(\mathrm{MPa})$ & $\mathrm{Et}(\mathrm{MPa})$ & $\mathrm{Dsb}\left(\mathrm{g} / \mathrm{cm}^{3}\right)$ & $\mathrm{MOR}(\mathrm{MPa})$ & $\mathrm{MOE}(\mathrm{MPa})$ \\
\hline \multirow{3}{*}{ Matriz } & $\mathrm{HDPE}$ & $1,02 \mathrm{c}$ & $20,0 \mathrm{~b}$ & $1362 \mathrm{~b}$ & $0,95 \mathrm{a}$ & $36,0 \mathrm{~b}$ & $1347 \mathrm{~b}$ \\
& $\mathrm{PP}$ & $0,98 \mathrm{~b}$ & $26,1 \mathrm{c}$ & $1766 \mathrm{c}$ & $0,96 \mathrm{~b}$ & $51,6 \mathrm{c}$ & $1701 \mathrm{c}$ \\
& $\mathrm{LDPE}$ & $0,97 \mathrm{a}$ & $9,7 \mathrm{a}$ & $401 \mathrm{a}$ & $0,98 \mathrm{c}$ & $15,9 \mathrm{a}$ & $407 \mathrm{a}$ \\
& Fcalc & $186,5^{*}$ & $424,3^{*}$ & $560,1^{*}$ & $17,7^{*}$ & $5546,5^{*}$ & $382,1^{*}$ \\
\hline \multirow{2}{*}{ Harina } & & $0,93 \mathrm{a}$ & $19,1 \mathrm{~b}$ & $767 \mathrm{a}$ & $0,93 \mathrm{a}$ & $28,7 \mathrm{a}$ & $814 \mathrm{a}$ \\
& \multirow{2}{*}{$\mathrm{Pt}$} & $1,01 \mathrm{~b}$ & $20,4 \mathrm{c}$ & $1433 \mathrm{c}$ & $1,01 \mathrm{~b}$ & $41,7 \mathrm{c}$ & $1542 \mathrm{c}$ \\
& $P t C$ & $1,02 \mathrm{c}$ & $16,3 \mathrm{a}$ & $1329 \mathrm{~b}$ & $0,94 \mathrm{a}$ & $33,2 \mathrm{~b}$ & $1100 \mathrm{~b}$ \\
& Fcalc & $755,4^{*}$ & $26,6^{*}$ & $146,0^{*}$ & $146,1^{*}$ & $756,7^{*}$ & $114,9^{*}$ \\
\hline Interacción & Fcalc & $18,5^{*}$ & $20,0^{*}$ & $14,9^{*}$ & $89,4^{*}$ & $170,1^{*}$ & $18,9^{*}$
\end{tabular}

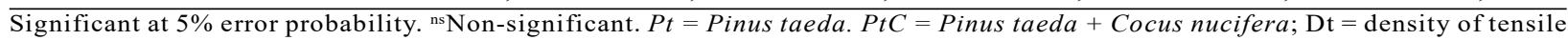
specimens; $\mathrm{St}=$ tensile strength; $\mathrm{Et}=$ tensile modulus; Dsb = density of static bending specimens; MOR = static bending strength; MOE $=$ static bending modulus; Means followed by the same letters do not differ statistically by Duncan test at $5 \%$ error probability.

Fiber aggregates were not observed in any case. Hillig et al. (2008) detected the formation of fiber aggregates in composites produced with HDPE and different types and grades of wood flour. SEM analysis showed a relationship between particle size and aggregate formation, and for the fine wood flour from MDF there was no aggregate formation.

In general, the composites produced with PP and Loblolly Pine wood flour presented the most homogeneous structure, followed by HDPE and LDPE, both with Loblolly Pine flour. The mixture of coconut shell flour with Loblolly Pine wood flour caused the presence of voids in the composites produced with all types of matrices. The HDPE composites presented larger voids, however, the PP composites showed a large number of small voids.

\subsection{Mean values of evaluated properties}

The mean density values of the specimens produced by injection with the pure matrix are consistent with the figures presented in the Braskem technical catalog for the type of plastic material used (BRASKEM, 2015). The mean values of the mechanical properties are close to the values obtained in other studies, such as Grison et al. (2016), for the tensile strength and tensile modulus of HDPE and Hillig et al. (2011), for static bending properties, except for the pure HDPE elastic modulus which was significantly higher.

The values found in this study also agree with the values obtained by Lee et al. (2010) for the static bending properties of the three polymers (LDPE, HDPE and PP), respecting the differences in the methodologies used in production and in the tests.

The composites showed a higher density than pure matrices, except for the static bending specimens produced with HDPE, Loblolly Pine and coconut shell mixtures (T3). In Figure 2, the presence of more voids is observed in these specimens, even more than in the tensile specimens made from the same formulation. This fact demonstrates the importance that can also

Revista Árvore. 2017;41(4):e410412 
have the produce process (injection) on the characteristics of the specimens produced.

The fact that the static bending test specimens of the T3 composites showed lower density than expected was attributed to the presence of excessive moisture in the granules during the injection process. The presence of such excess moisture, due to some failure in the previous drying process, caused the formation of water vapor during the injection molding which led to the formation of the bubbles observed in these specimens.

Hillig et al. (2011) found mean density values equal to 1.02 g. $\mathrm{cm}^{-3}$ for injected pieces produced with HDPE composites and pine and MDF wood flours, used in the proportion of $40 \%$, values close to those found in this research for the other test specimens produced with HDPE matrix. In papers evaluating the properties of PP and LDPE composites with wood, no mean values of density of pieces were found for comparison.

The mean values of tensile strength and tensile modulus found for the specimens produced with the different matrices and with the different composites also varied according to the characteristics of each matrix, and are in a range close to the values found in some researchs with composites. Redighieri and Costa (2008) found mean values of St equal to 11.2 MPa and 18.6 MPa for eucalyptus wood composites and recycled LDPE without and with compatibilizing agent, respectively. However, the mean value obtained for the pieces produced with the pure matrix was $21.1 \mathrm{MPa}$, showing that the variation occurred between the pure matrix and the LDPE composites of that research varied in a way analogous to the variation occurred in this study (Table 2).

In a study with composites of PP (70\%) and Loblolly Pine wood flour (30\%) without coupling agent, Battistelle et al. (2014) found St values of 20.13 MPa and Et of $2170 \mathrm{MPa}$, respectively. The value of modulus of elasticity is similar to that found in this study for T5, while the strength value is lower. The mean values found by the authors for pieces with pure matrix were $22.12 \mathrm{MPa}$ and $1000 \mathrm{MPa}$, respectively, both inferior to those found in this study.

For HDPE and wood, Hillig et al. (2008) found mean values of St ranging from 20.1 to $25.7 \mathrm{MPa}$ for injected pieces of composites produced in single-screw extruder with a $30 \%$ proportion of different sawdust types.In the same line, Hillig et al. (2011) found values ranging from 32.1 to 35.1 MPa for injected pieces of composites produced in a double-screw extruder with $40 \%$ of sawdust ratio of pinus and MDF. The values found in both studies for pieces injected with pure HDPE were 19.4 MPa, higher than that found in this study.

\subsection{Factor analysis of Physico-mechanical properties}

The incorporation of flour increased the composite density in relation to its pure matrix, except for the static bending test specimens produced with a mixture of Loblolly Pine flour and coconut shell, caused by the injection problems already mentioned.

The tensile strength was higher for the PP matrix, followed by HDPE and LDPE, being in agreement with each matrix theoretical characteristics and with the study of Lee et al. (2010). In the main effects analysis, it can be seen in Table 3 that, in general, the addition of Loblolly Pine flour increased the tensile strength (St), while the addition of the Loblolly Pinecoconut shell mixture caused a decrease in relation to the pure polymer. The interaction analysis shows that, for HDPE, the use of Loblolly Pine wood increased St and the Loblolly Pine-coconut shell mixture maintained similar values to the pure matrix. Considering the PP matrix, the addition of Loblolly Pine flour produced St values similar to the pure matrix, and the flour mixture use (Loblolly Pine and coconut) caused a decrease in this value. With the LDPE matrix, there was a St decrease using both flours types in relation to the pure matrix.

This fact is related to the adhesion between fiber and matrix and the influence caused by the coupling agent use. The effect was small for LDPE matrix, followed by the PP matrix and HDPE, which presented the best result of tensile strength in relation to the pure matrix when mixed with Loblolly Pine flour. On the other hand, for HDPE and PP, it was verified that the tensile strength was lower with the use of coconut shell flour and for LDPE there was this tendency, although it was not confirmed in the statistical analysis.

Oliveira et al. (2010) obtained mean values of 12.2; 13.4 and 17.1 MPa of tensile strength in the evaluation of composites produced with pure LDPE, LDPE and $5 \%$ of green coconut fiber without coupling agent, and LDPE and 5\% fiber with coupling agent, respectively. Thus, future studies may consider the addition of a higher ratio of coupling agent in the mixture in an attempt 
to improve interfacial adhesion, taking into account that these agents are still of relatively high cost.

The evaluation of tensile elastic modulus shows that the composites stiffness was increased with the flour addition, and that it was higher in the composites produced with Loblolly Pine flour than in the mixture with coconut shell flour. However, in the analysis of the interaction, it is verified that this affirmation was confirmed statistically for the composites produced with PP matrix, whereas with the HDPE and LDPE matrices there was no statistical difference of the tensile elastic modulus between the pieces produced with Loblolly Pine flour and those produced in a mixture of coconut shell.

In the static beding properties analysis, higher resistance (MOR) and the stiffness (MOE) of the composites in relation to their pure matrices were verified, except for MOR of PP with coconut shell flour. In addition, the pieces strength and the stiffness were higher for the composites produced with Loblolly Pine flour than for those produced with a mixture of Loblolly Pine and coconut shell. In part, this fact is due to the smaller size presented by the coconut shell particles and, on the other hand, it is also due to the lower interfacial adhesion verified by scanning electron microscopy and tensile strength values.

Hillig et al. (2011), when evaluating composites produced with HDPE, and Izecor et al (2013) evaluating composites produced with LDPE, verified the effects of particle size on the static bending properties, concluding that an increase in particle size causes increased MOR and MOE. In addition, Hillig et al. (2008) commented that even in a system with low interfacial adhesion this can occur. It is observed, therefore, that the magnitude of increase of MOR and MOE of the composites in relation to its pure matrix depends on the particle size and on the interfacial adhesion.

\section{CONCLUSIONS}

In general, the composites presented a satisfactory wood flour distribution in the polymer matrices, but the addition of coconut shell flour promoted the formation of voids or bubbles in the pieces. The coupling agent use to improve interfacial adhesion had better perfomance with the high density polyethylene matrix, followed by that of polypropylene and low density polyethylene.

The addition of coconut shell flour in the composites caused reduction in the tensile strength, static bending strength and stiffness. The coconut shell flour presented no differences in tensile rigidity in relation to composites produced exclusively with Loblolly Pine flour.
For the LDPE polymer matrix, the addition of two types of flour caused a reduction of the tensile strength in relation to the pure matrix. For the HDPE matrix, the two flours types improved the mechanical properties, except the tensile strength of the composite with flour mixture, which maintained a similar value to the pure matrix. In the case of the PP matrix, the use of coconut shell flour decreased the tensile strength, maintained the static bending strength and increased the composites stiffness, both in tensile and in static bending, in relation to the pure matrix.

\section{ACKNOWLEDGMENTS}

The present study was carried out with the support ofCNPq, National Council of Scientific and Technological Development - Brazil; the UNICENTRO, Midwestern State University; UPM, Madrid Polytechnic University; and UCS, Caxias do Sul University.

\section{REFERENCES}

Associação Brasileira de Normas Técnicas ABNT. NBR 11941. Madeira - Determinação da densidade básica. Rio de Janeiro: 2003.

ADDIVANT $^{\mathrm{tm}}$. Technical Information - Polybond 3009. Bellevue:Chempoint; 2013.

Battistelle R, Viola NM, Bezerra BS, Valarelli IDD. Caracterização física e mecânica de um compósito de polipropileno reciclado e farinha de madeira sem aditivos. Revista Matéria.2014;19(1):7-15.

BRASKEM. Poliolefinas - tabelas de propriedades. São Paulo: 2015. 32p.

El-Haggar SM, Kamel MA. Wood plastic composites.In: Tesinova P editor Advances in Composite Materials - analysis of natural and man-made materials.InTech; 2011. Available from: http://www.intechopen.com/books/advances-incomposite-materials-analysis-ofnatural-and-anmade-materials/wood-plastic-composites.

Colli A, Vital BR, Carneiro ACO, Silva JC, Carvalho AMML, Della Lucia RM. Propriedades de chapas fabricadas com partículas de madeira de paricá (Schyzolobium amazonicum Huber ex. Ducke) e fibras de coco (Cocos nucifera L.). Revista Árvore. 2010;34(2):333-8. 
Grison K, Pistor V, Scienza LC, Zattera AJ.The physical perspective on the solid and molten states associated with the mechanical properties of eco-friendly HDPE/Pinus taeda wood-plastic composites. Journal of Applied Polymer Science.2016;133:1-6.

Hillig É, Iwakiri S, Andrade MZ, Zattera AJ. Caracterização de compósitos produzidos com polietileno de alta densidade (HDPE) e serragem da indústria moveleira. Revista Árvore.2008;32(2):299-310.

Hillig É, Iwakiri S, Haselein CR, Bianchi O, Hillig DM. Caracterização de compósitos produzidos com polietileno de alta densidade (HDPE) e serragem da indústria moveleira - parte II extrusão em dupla-rosca. Ciência Florestal. 2011;21(2):335-47.

International Organization for Standardization ISO. ISO 178:2010/Amd.1:2013(E). Plastics Determination of flexural properties.

International Organization for Standardization ISO. ISO 527-1: 2012. International Standard EN. Plastics - Determination of tensile properties Part 1: General principles.

International Organization for Standardization ISO. ISO 527-2: 2012. International Standard EN. Plastics - Determination of tensile properties Part 2: Test conditions for moulding and extrusion plastics.
Lee C-H, Wu T-L, Chen Y-L, Wu J-H.

Characteristics and discrimination of five types of woodplastic composites by FTIR spectroscopy combined with principal component analysis. Holzforschung.2010;64:699-704.

Oliveira TÁ, Teixeira A, Mulinari DR, Goulart SAS. Avaliação do uso de agente compatibilizante no comportamento mecânico dos compósitos PEBD reforçados com fibras de coco verde. Cadernos UniFOA.2010;5(14):1-7.

Optimat Ltda/Merl Ltda. Wood plastic composites study - technologies and UK market opportunities. Wrap Research Report. Banbury: The Old Academy; 2003.

Redighieri KI, Costa DA. Compósitos de Polietileno Reciclado e Partículas de Madeira de Reflorestamento Tratadas com Polietileno Modificado. Polímeros: Ciência e Tecnologia.2008;18:5-11.

Silva R, Haraguchi SK, Muniz EC, Rubira AF. Aplicações de fibras lignocelulósicas na química de polímeros e em compósitos. Química Nova.2009;32(3):661-71.

Sindicato das Indústrias de Material Plástico SIMPLÁS. Boletim Informativo do Seminário Internacional sobre WPC. n. 38, Dezembro/2008.

Tobón AED, Chaparro WAA, Rivera WG. Mejoramiento de las propiedades de tensión en WPC de LDPE: HIPS/Fibra Natural Mediante Entrecruzamiento con DCP. Polímeros.2014;26:1-9. 